\title{
The Ohu Movement
}

\section{LYMAN TOWER SARGENT}

New Zealand has a long history of intentional communities or communes that were established to bring about a life desired by its members that they did not believe was possible in mainstream society. ${ }^{1}$ The earliest such communities in New Zealand were in the middle and latter half of the nineteenth century, and a continuous tradition developed with the Beeville Community about 1933. Such communities are found throughout the world, but New Zealand is unusual in having had a government-sponsored scheme to establish them. ${ }^{2}$ This scheme was known as the Ohu movement, and it came about in 1973 under the initial sponsorship of Norman Kirk.

The history of the Ohu Movement is one of great enthusiasm, followed by growing disillusionment. But it is a fascinating story of hope and effort against bureaucratic opposition. In this situation, communities were actually established, and one still exists. Their stories have never been told, and although later an Australian Prime Minister spoke of doing the same thing, he didn't, and it remains an unique part of communal history, the closest analogues being the Kibbutz Movement in Israel and the U.S. Farm Credit Administration communities during the Depression, and neither of these is even a close parallel.

On 10 October 1973, Margaret Haywood noted in what was published as her Diary of the Kirk Years:

Although $\mathrm{Mr} \mathrm{K}$ has been pushing kibbutz-type collectives as an alternative life-style he's having trouble getting the idea across to the New Zealand public. But he's got through to Peter Robinson of the Australian Economic Review who noted Mr K "returned again and again" to the need for young New Zealanders to contribute with their own hands and sweat to the building of the nation. ... He saw a kibbutz-type environment as an antidote to the ills of modern society, as well as a means of showing people the virtues of a simpler life.

Yesterday Mr K made it official policy. He announced that Mat Rata as Minister of Lands, and Arthur Faulkner who is Acting Minister of Lands while Mat is convalescing, would look into the possibility of making Crown land available for people of all ages to participate in settlements run on similar lines to the kibbutz system in Israel. He did not particularly like the word kibbutz but so far could find no Maori equivalent. $^{3}$

There is no agreement on who actually originated the idea. Each name that has been put forward is strenuously rejected by at least one person close to the early developments.

Young people greeted the announcement with great enthusiasm. The pattern of enthusiasm followed by growing doubts about the willingness of the government to actually go through with the scheme, followed by bitter disillusionment can be followed through the three versions of The New Zealand Whole Earth Catalog and the pages of Mushroom, particularly the latter.

On 1 December, Hayward added, quoting Kirk:

The main theory behind this kibbutz idea is to let young people work out a life-style that isn't determined by money.

I want to see real equal opportunity being shared and to throw the door open for people. We can wipe out this personal housing backlog in three years if local bodies will co-operate.

The government can't change people's life-style. But it can create the opportunity to let people work it out for themselves. ${ }^{4}$

In the pamphlet later published by the Ohu Advisory Board, Kirk's reasons for the proposal were said to be:

... mainly spiritual. From the start he spoke about the need to involve people more deeply in the affairs of the community as a whole.

He said that in the last few years a lot of young people had been saying that the Establishment had gone soft, that it had lost its ideas and its drive. The people who said this, those who were disillusioned with the way things were going, were to be given an opportunity to see if they could do what they said should be done. They were being given this opportunity because there was a place in nation-building for them. ${ }^{5}$

In the same vein Matiu Rata spoke to the Ohu working party in August 1974, saying

The over-emphasis on the gross national product, perpetual greed, speculation, profiteering, unethical practices and the cult of individualism can only result in the further alienation of those who seek a return to community and group feelings. I share with other Government members the hope that the Ohu will, in some way, lead the way to a more concerned society and recapture anew the deep links of people and land.

There is hope, too, that it will soften the harsher aspects of much of New Zealand's life style and result in a finer quality of life. Since many individuals and groups have expressed the desire to adopt different life styles, and as some are already living this way, we cannot neglect the opportunity of letting New Zealanders and their friends recapture the satisfaction based on cooperation, mutual assistance and communalism, which had been the force which motivated both the first Maori and the first European settlers of this land.... 


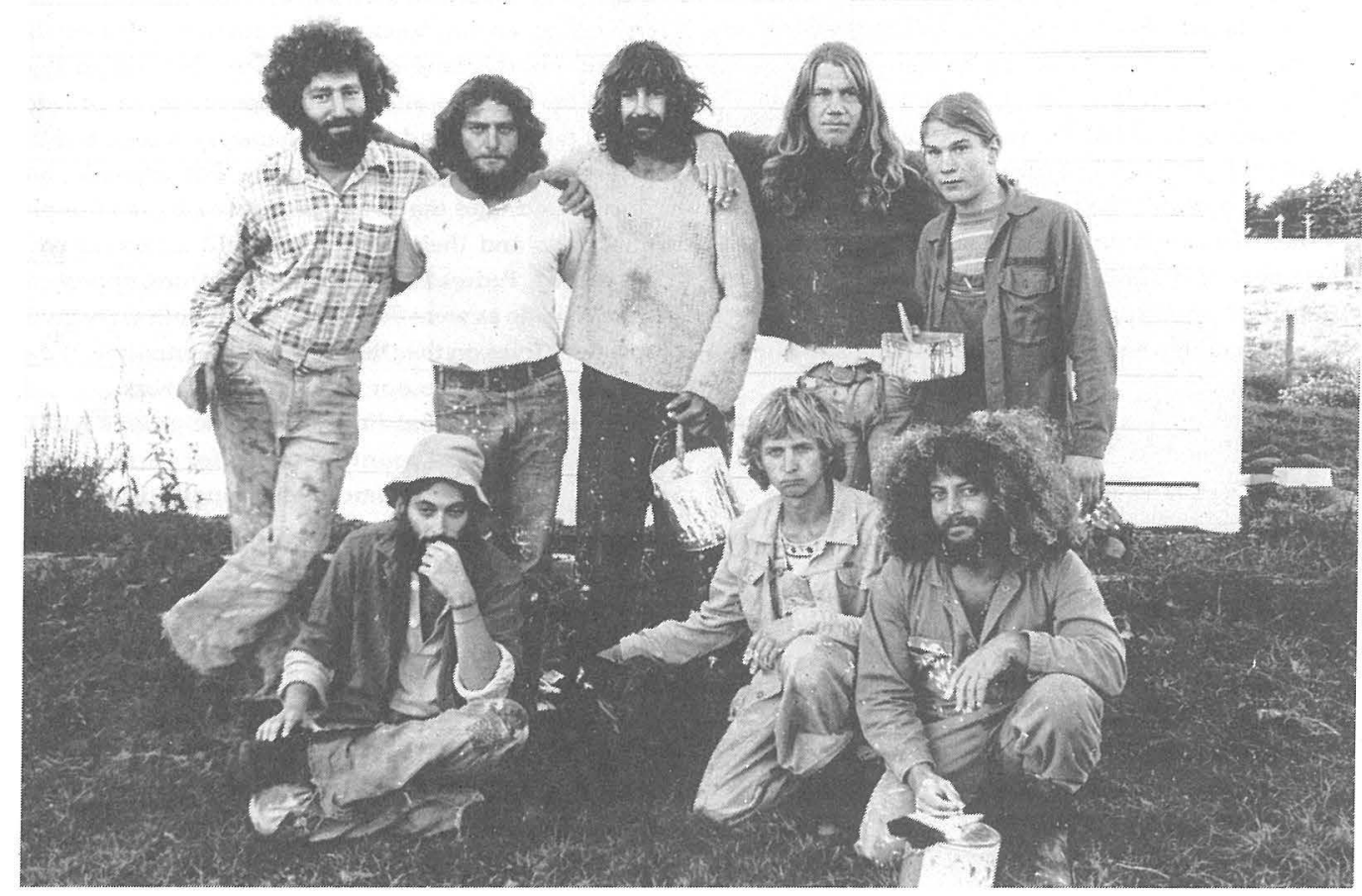

It is not meant to be a cheap method of developing marginal lands-it is meant to give an opportunity to New Zealanders to experience the earth, the country, and each other in a new fraternal way. ${ }^{6}$

Much happened between these two statements of intent with their positive sense of the possibilities of the scheme. The official statement of the process is that Arthur Faulkner, Acting Minister of Lands and a supporter of the scheme, developed guidelines within the department, and,

In early December [1973] it was agreed that the main objective of the settlements would be to offer to the participants an alternative way of life. The land would not have to be developed in any specific way, nor would there be an obligation to create an economic unit that was fully efficient in terms of normal agricultural development. On the agricultural side, settlements would probably aim for self-sufficiency or even a slight surplus, and other activities such as cottage crafts could develop; but these decisions would be made by the participants.

It was decided that the Government should be prepared to lease Crown land to groups but the choice of the actual areas of land would be worked out with the intending participants. Regulation of the affairs of communities would be the concern of the communities

Members of the Jerusalem community. Evening Post, 26 April 1975, \#1686/75. themselves; they should establish their own rules rather than be tied rigidly to Government guidelines. ${ }^{7}$

These proposals met, as I have said, with great enthusiasm and high expectations. But on 7 March, Margaret Hayward wrote:

Arthur Faulkner, still Acting Minister of Lands, has announced that the proposed communes will be called "ohu" - a Maori word meaning to achieve something "by means of friendly help and work". But press officer Peter Kelsey, who has transferred from our office to work on the scheme, of which he is an enthusiastic advocate, tells me the Lands and Survey Department has decided that applicants should have only land designated as suitable for nothing else, "and that's pretty bad land to go on to". 8

The Ohu scheme appears to be a classic case of an idea coming from the top levels of government and being almost immediately undermined by the bureaucracy.

Although there is evidence that Faulkner and Rata later tried to overcome this situation, I contend that at this point, four months after its initial announcement, the Ohu scheme was deliberately killed by the Department of Lands and Survey.

Still, the enthusiastic people anxious to join the scheme didn't know that their hopes had already been rendered virtually impossible, supporters worked hard to make the scheme work, and they met with such enthusiasm and support from the target community that some things happened despite Lands and Surveys. 
As a result the bureaucracy went through the motions of supporting policy while making sure that the communities failed, and the fact that one still exists over twenty years later is testimony to the strength of the feeling the scheme touched.

A meeting attended by over 100 people was called at Elsdon, Porirua on 13 February 1974. At the meeting a working party of 15 was formed, including members of established communities and people who wanted to create new communities. By August 1974 twenty-five groups had been approved, one, called Sunburst, had started, no others had found land, and one had already disbanded.

Initially Lands and Surveys requested its district offices to provide a list of land in their areas suitable for Ohus. Virtually none had any. This response was found unacceptable, and, after a series of revised directives, the district offices were ultimately required to produce lists of all unoccupied land in the district. It turned out that land was available in all districts.

Anyone familiar with bureaucracies will know that forcing them to respond differently from their initial statement is not the way to gain their support. Even though they had already demonstrated their opposition to the scheme, the districts were later given control over the process, driving another nail into the Ohu coffin.

The working party met until September, and in December the Ohu Advisory Committee was officially established. It published a pamphlet outlining the history of the movement and laying down the procedures for the future.

The guidelines specified that:

1. Each Ohu must have a minimum of eight adults (initially fifteen but lowered).

2. "Every ohu group must form itself into some kind of legal entity." A limited liability company was suggested and groups were encouraged to consult a lawyer.

3. Most members of each group must be New Zealand citizens.

These general guidelines probably posed few problems for the groups. Still, the need to set themselves up as a limited liability company using a lawyer to do so undoubtedly went against the grain for many, but a limited liability company made the lower number of participants possible.

These general guidelines only introduced the actual procedures, and these procedures were the stroke that killed the Ohu scheme. In the initial stages of the development of the scheme, there was a central office in Wellington which dealt with all issues, but now parts of the process were decentralized. The groups were told to contact the district office in which they hoped to settle. They then had to examine the available land and choose a site. 'When a site has been agreed on, group representatives and district offices should work out the area to be leased and also discuss other relevant matters such as access, fencing and valuation. ${ }^{\prime 9}$ If they did not find suitable land in their preferred area, they then had to move on to another district office. In practice little of the land found suitable had easy access, and the groups had to negotiate for access. For example, one group found land that was surrounded by land in private hands and their request to build an access road was denied. Federated Farmers were strong opponents of the scheme as were Forestry people. Both were given representatives on the Ohu Advisory Committee. If this was an attempt to co-opt them, it didn't work.

But the biggest hurdle was that the groups had to negotiate with local county councils for permission to build on the land. 'In some cases groups will fit into a predominant use of the Rural A zone, but in other cases groups will eventually want to erect more dwellings on their site than are allowed for in their particular district scheme, and "conditional use" applications or "specified departures" will be required.' 10 One example of what happened when this occurred is found in Croixilles Ohu Ltd v Marlborough County Council.

This appeal was for a change of use and specified departure to permit the construction of nine cottages and other buildings on land containing 20 hectares and zoned Rural A in the proposed district scheme. That zoning would not permit more than one dwellinghouse as of right. The appellants sought to establish a community where they can manufacture goods for an outside market and produce their basic food requirements.

Held, (disallowing the appeal): (1) In effect the proposal is for the creation of a small village dependent on urban uses. Granting the application would have significance beyond the vicinity by creating a precedent. Great difficulty would be experienced in distinguishing persons genuinely interested in communal living from those grouping themselves together to circumvent the scheme. [The Ohu had gone through the lengthy procedures laid down by the Ohu Advisory Committee and been approved.]

(2) Granting the application would be contrary to the public interest in that it would promote sporadic residential development in a rural zone. ${ }^{11}$

Later they say:

'They propose to make and sell-a wide range of goods, but on the evidence before it, the Board has serious doubts as to the viability of the venture. ${ }^{12}$

And any dwellings built must satisfy local building codes. While this did not pose a problem for some, it clearly undermined the desire for other groups to establish an alternative life style. According to Mushroom, government wrote to the Counties Association telling it that ohu would have '... to meet all existing by-laws and regulations of the local bodies concerned.'13 Mushroom adds that it is expected the central government 
would assist the groups with "overly severe" applications of the rules. The belief in this intent is regularly repeated and could be mere wishful thinking, but there is some evidence that in the initial stages, some mediation was forthcoming, and Peter Kelsey accompanied some groups in their meetings with local bodies, but that didn't last.

Finally, it is worth noting that the land was not precisely free, but rented at ' ... 4 $1 / 2 \%$ of the current market value of the ohu site ${ }^{\prime}$ and each time the lease is renewed, the rent is adjusted. Payment of the first year's rent was required in advance, and, given the nature of the land, was probably quite low. And if they made an undefined "satisfactory progress", future rent would remitted for up to three years.

Proposals had poured in to the Working Party before the detailed guidelines were developed. Later, these proposals were described as follows:

From the proposals of the groups that came forward during the first months of the scheme it is apparent that there are common characteristics. Most groups seek, and offer, an alternative, largely selfreliant, life style on the land. They are interested in organic agricultural methods and the recyciing of materials, in alternative technology and the decentralised generation of energy by non-pollutive methods. Groups are interested in the communal sharing of amenities and equipment, and in experimental social relationships. They are concerned about education and the need to look for and explore alternatives in this sphere, and they are interested in the exploration of alternative forms of architecture, uses of materials, forms of construction and methods of design [Obviously the last interest set up a potential conflict with building codes. $]^{14}$

These characteristics are an accurate description of one part of the alternatives movement of the time.

One community, Sunburst on Coromandel, got started before all the rules were laid down. A description published in 1975 says, 'The land is on the other side of the [Rangihau] river from the road and access is by foot, at present. A neighbouring farmer cut a bulldozer track across the river and up the hill. He is going to be repaid with labour. There are five gardens laid out (the heavy scrub had to be cleared first) and a temporary dwelling for the family. Everything has had

Norman Kirk, 1973. Evening Post \#1703/73.

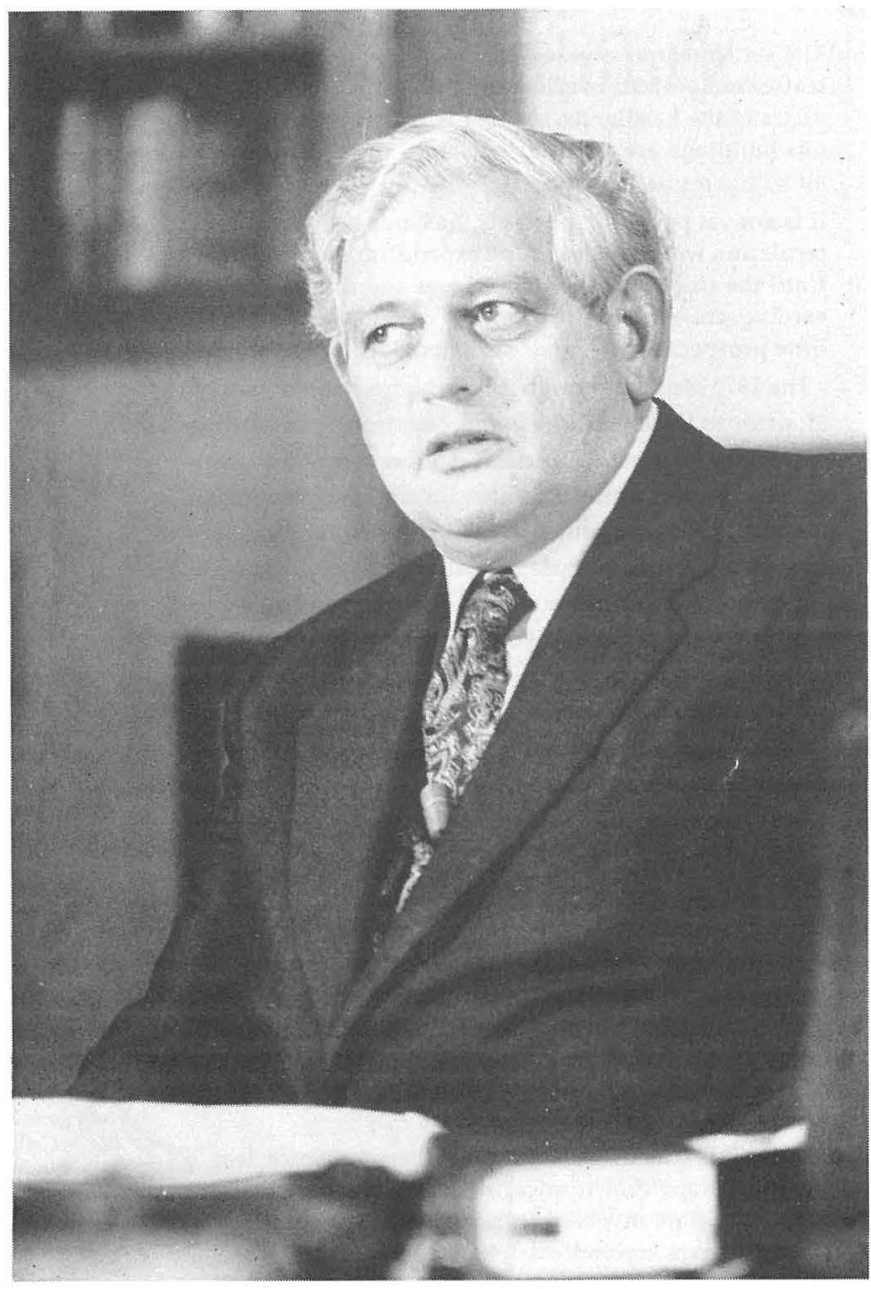

to be carved out of the bush. They have a license to use 80 hectares (200 acres) for a year.' ${ }^{15}$

There were, of course, communes established during the same period outside the Ohu scheme, and in some support of my argument, they generally survived for a longer period and more of them still exist.

The only commune established under the Ohu scheme that still exists is the Ahu Ahu Ohu, on the Ahu Ahu River. At first access involved rowing across the Wanganui River and walking along a bush track for 50 minutes. It recently celebrated its twenty-first year on the land, and '... over the years and with hundreds of hours of hard slog we how have a $2 \mathrm{~m}$ track capable of taking all three and four wheeled terrain vehicles with small trailers. ${ }^{16}$

Another ohu that got onto the land and struggled unsuccessfully to survive was the Earth Extract Ohu. Initially it succeeded through support from members working in Auckland who hoped to be able to later move onto the land. In 1981, Earth Extract was described as follows: 
The settlement is situated in the middle of scrub and teatree on low hills overlooking the Waipu plains with views of the headlands, sea and islands beyond. Various buildings are in different stages of construction, all within a small area....

It is not yet possible to live off the land-it is not very fertile and would require high expenditure to develop. Until the size of the group increases and some income earning project from the land is developed, there is little prospect of being self-sufficient. ${ }^{17}$

The 1975 election brought in the National Party which had, prior to the election, announced its support for the ohu scheme. After the election it wound up the Advisory Committee, removed Peter Kelsey, and shifted all authority to Lands and Surveys, thus removing any input from people wanting land or already living in communes. Acceptability to the local community was added as one of the criteria for acceptability, and rather than being set aside for ohu, any land available had to be publicly advertised and made available to anyone.

In 1974 Mushroom published a letter from the Waimea Ohu, one that never got land. It reads in part:

We have made three applications for sites on the West Coast north of Westport, two of which have been turned down and the third is still in the pipeline (although we don't hold too much hope). It has taken almost 18 months to get this far and as many of you probably know by now it is hard to keep a large group enthusiastic for that length of time when they could be pursuing other ways of getting some land. ${ }^{18}$

Delay was clearly a tactic to defeat the scheme. As was noted in the next issue of Mushroom:

... the Ohu scheme seems to have become much less the great hope that it once was; mainly through the amount of time involved (can be up to 2-3 years), the energy in writing endless letters to bureaucrats and the overall uncertainties as to whether the groups will gain the land they seek anyway. ${ }^{19}$

The bureaucrats had won. It had taken only two years to deliberately destroy the dreams of hundreds of wellmeaning if naive young people.

To be fair to the bureaucrats that naivete should not be overlooked. As one commentator put it:

The Labour government's Ohu Scheme failed for varied reasons. The realities of these groups of up to twenty individuals, mostly from the cities, moving onto a block of land were not really considered. First, the land allocated to the groups was mainly scrub and bush covered, hard to break in. In a lot of cases access was extremely difficult, and many of the sites were too remote from towns and cities to enable the people living within to earn money for establishing and developing their community. ${ }^{20}$

Also, Ohu members were not all agreed on what they wanted to achieve, and the failure to resolve these differences in advance brought tension and potential failure. For example, some people were interested in creat- ing viable farms and even communities that would last and provide a basis for a different way of life while others wanted to drop out and live as simply as possible on the land.

And communal life proved difficult for many. Living in a commune is more like a marriage than a business and experience elsewhere suggests that creating a lasting group takes foresight, insight, and continued hard work. Many Ohu were created from people who had known each other for a long time and had even already been living communally, but others were created for the purpose of forming an Ohu. Many advertised in the pages of Mushroom for members to bring the number up to the eight required by the regulations, and this boded ill for the longevity of the groups advertising, but most were never given the chance to try.

\section{NOTES}

1 I define an intentional community (the most commonly used term today) or commune as a group of five or more adults and their children, if any, who come from more than one nuclear family and who have chosen to live together to enhance their shared values or for some other mutually agreed upon purpose. For a discussion of this definition, see Lyman Tower Sargent, 'The Three Faces of Utopianism Revisited.' Utopian Studies 5, no 1 (1994), pp 13-17. For a preliminary listing of $\mathrm{NZ}$ intentional communities see Lyman Tower Sargent, New Zealand Intentional Communities A Research Guide occasional Paper 96/2 Stout Research Centre, VUW (forthcoming).

2 The Kibbutz Movement in Israel and some agricultural communities founded in the United States during the Depression are the other examples. The Chinese communes were a different category of experiment altogether.

3 Margaret Hayward, Diary of the Kirk Years (Queen CharlotteSound: Cape Catley/Wellington: A. H. and A. W. Reed, 1981),p 173.

4 Ibid, p 183.

5 Ohu: Alternative Lifestyle Communities (Wellington: Published for The Ohu Advisory Committee by the Department of Lands and Surveys, 1975),p 3 .

6 Ibid, $\mathrm{p} 4$

7 Ibid, pp 5-6

8 Hayward, p 223. According to Brian Easton, a member of the Working Party, the word was chosen by the Working Party. There were no Maori members.

9 Ohu, p 1.

10 Ibid, $\mathrm{p} 12$

116 NZTPA 74 (12 August 1976)

12 Ibid,p 75.

13 'Ohu.' Mushroom, no 1 ([1974]), p 7

14 Ohu, p 3

15 Malcolm McSporran, 'The Sunburst Community or The divine light can hardly be seen for the trees.' In The 2 nd New Zealand Whole Earth Catalogue. Edited by Dennis List and Alister Taylor (Martinborough, New Zealand: Alister Taylor, 1975), p 29

16 Ahu Ahu Ohu, 1992 Information Sheet

17 A Guide to Co-ops (Auckland, New Zealand: Auckland University Environment Group, 1981), pp 40-41

18 'Ohu Where To Now?' Mushroom, no 4 (Summer 1976) p 11

19 'Ohu.' Mushroom, no 5 (Autumn 1976), p 15

20 'A Viable Alternative.' In Nambassa: A New Direction (Wellington, New Zealand: A.H. \& A.W. Reed, 1979), p 7 